\title{
From Arab Spring to Economic Winter - examination of the relationship between politics and economics as evident in the syrian civil war during 2011-2015
}

\author{
Erez Cohen \\ Ariel University \\ Israel \\ erez@ariel.ac.il
}

\begin{abstract}
This study emphasizes the relationship between politics and economics as evident in the Syrian civil war by presenting the economic consequences of the drawn-out civil war in Syria and examining the effect of this war on the country's major economic indicators during 2011-2014. The research findings show that the continued fighting in Syria has had a harmful effect on the local economy and as a result the GDP is declining and its structure is changing, unemployment is on the rise, and the budgetary deficit is growing. This effect is also examined in comparison with Egypt and Libya, countries that underwent internal conflict and governmental chaos, reaching the conclusion that the Syrian economy was more deeply affected by the unstable security situation than the former countries. Syria's economy is disintegrating both internally and externally, gradually becoming irrelevant for global trade in general and for the oil trade in particular and losing its place to its competitors in this field. It is also encountering particularly acute internal political and socioeconomic problems, raises doubts as to Syria's ability to survive this volatile period and to sustain its government in the future. Nonetheless, it appears that Syria’s slight chances of economic recovery depend primarily (or even exclusively) on international interests, further clarifying the claim concerning the major role and impact of external factors on a post-war country's chances of economic recovery and stabilization.
\end{abstract}

Keywords: Civil War, Syria, Political Economy

JEL classification: P16, N45

\section{INTRODUCTION}

The purpose of this study is to analyze the relationship between politics and economics as evident in the Syrian civil war. This war, that began in 2011 as an uprising of local rebel groups against the Alawite government of President Asad, rapidly developed into full-scale fighting, once other factors with their own political and military interests joined in. As the fighting proceeded, it became clear that what had begun as a political crisis had developed into an extensive economic crisis.

The current paper analyzes the economic implications of the fighting and explores the effect of this vicious and harsh civil war on Syria’s economy, focusing on its main indicators: gross domestic product, 
exports, unemployment, and foreign investments. This review will proceed by locating and analyzing data from the World Bank database, as well as other databases such as that of the Syrian Centre for Policy Research (SCPR), the Economic and Social Commission for Western Asia (ESCWA), and the Economist Intelligence Unit (EIU).

Such a study dealing with a current issue has a preexisting limitation as a result of the fact that the fighting in Syria has not yet ended and is becoming even more complex with the addition of Russian and Iranian forces (and, indirectly, also French and American forces). Nonetheless, the study appears to contribute to the current literature on the effect of wars (including civil wars) on a country's economy as well as on the relationship between external economic-political factors and the country's economic post-war recovery.

The research literature is replete with publications that point to an association between war and changes in domestic economic indicators, presenting and exploring the various factors that affect this association. Some studies claim that war has a direct and immediate detrimental effect on these indicators, as fighting paralyzes or at least moderates overall consumer activity since citizens are in a state of anxiety and tension and are reluctant to venture out to shopping centers and entertainment venues. The drop in consumer activity has a direct effect on the economy's productive activity and leads to its decline. The reduced scope of production increases unemployment while also slowing down foreign trade and domestic exports. Furthermore, an economy at war is less attractive to foreign investors and hence foreign investments in the economy diminish. A situation in which indicators of personal consumption, exports, and foreign investments are affected might naturally lead to a drop in the gross domestic product composed of these indicators. Moreover, a drawn-out civil war is even more destructive to the local economy and has a deleterious effect on the country's capital accumulation due to the devastation, the unwillingness of investors to invest in a country that is in a state of security crisis, as well as capital flight beyond the country's borders (Collier, 1999).

Then again, other studies claim that war requires an expansion of the government budget for military purposes and for defense expenditures and therefore leads to a rise in the public expenditure indicator ${ }^{1}$ and incidentally compensates for the decrease in other GDP indicators, creating a positive effect on the country's total GDP (Yang and Lester, 1994). These studies are supported by economic data from several countries during and after a period of hostilities, which clearly indicate the positive effect of the conflict period on the economic indicators of these countries and primarily on the GDP and unemployment (Cohen, 2015). An example in case is the sharp rise in the US gross domestic product (GDP) during 1941-1945 (World War II), the most significant rise in this indicator in such a short period throughout the economic history of the United States. Furthermore, the sharp drop in the US rate of unemployment ${ }^{2}$ upon the conclusion of World War II in 1945 reinforces this concept of the positive effects of war on this indicator. Another study, which also claims a positive effect of war on the economy, shows an association between war and massive capital infusion by foreign countries and private investors at the conclusion of a war, contributing to the economic development of the country (Stubbs, 1997). An example of this claim is the case of Afghanistan in the years after the Taliban rule was overthrown, when a guerilla war emerged against the new government (Goodhand, 2004). Where the positive and crucial effect of international forces stationed in the country during 2005-2012 on the extent of foreign investments, employment, and the general domestic product was evident ${ }^{3}$.

1 Also included among the gross domestic product (GDP) indicators.

In 1945 the unemployment rate in the United States was only 1.9 .

GDP: (2004:1.1\%), 2005: 11.2\%, 2006: 5.6\%, 2007:13.7\%, 2008:3.8\%, 2009:21.0\%, 2010: 8.4\%, 2011: 6.1\%, 2012:14.4\%. Unemployment: 2005: 8.5\%, 2006:8.8\%, 2007:8.4\%, 2008:8.9\%, 2009:8.1\%, 2010:8.7\%, 2011:8.9\%, 2012:8.5\%. Source: World Bank : http://databank.worldbank.org/data. 
The ambivalent results evident from the studies cited above stress the contradiction between the positive effects of war on the economy and its negative effects. In this context, the report of the Institute for Economics and Peace $(2011)^{4}$ is notable as it compares the positive and negative effects of five wars and conflict situations ${ }^{5}$ experienced by the US economy over a period of some 70 years. ${ }^{6}$ These five wars indeed led to an increase in government military spending, contributing to increased demand and employment within the domestic economy and to the development of new technologies and generation of new industries. Then again, these government expenditures also resulted in a significant rise in the US budgetary deficit, primarily during World War II (1941-1945) (Ohanian, 1997), the cold war with the Soviet Union (late 1970s to mid-1980s) (Higgs, 2006) and the years of fighting in Afghanistan and Iraq (2003-2010) (Baker, 2007 ; Stiglitz and Bilmes, 2012).

Other studies that examined the effect of war on the various European economics reached the same conclusion as to the ambivalent association between increasing government military spending and the various economic indicators (Boskin and Lawrence, 1990).

If so, although the research literature abounds with publications on the effect of war on the economy, it appears that it is still not possible to determine unequivocally the direction of this effect, its intensity, and the time range in which it is manifested in the economic indicators. This uncertainty further highlights the research question underlying the current paper, with its attempt at diagnosing both the immediate and longterm impact of the civil war in Syria on the country's economic indicators. Before portraying and analyzing these indicators, however, a short background will be presented on the development of the Syrian "Arab Spring", which eventually turned into a murderous civil war.

\section{THE SYRIAN ARAB SPRING}

The series of political protests staged in the Arab world beginning from 2010 in Tunisia, Egypt, Yemen, Libya, and Syria, have been termed the "Arab Spring". Other Arab countries such as Algeria, Jordan, Morocco, Iraq, and Oman also experienced waves of civil protest manifested in large turbulent demonstrations, although these did not topple the regime. The political protests in the different Arab countries had unique diverse features (Anderson. 2011), however in all these countries two conspicuous interacting factors were at the root of these processes of civil uprising: one was economic and the other political. The economic factor had a very prominent role in the popular protests that emerged in Arab countries, as for many years they had suffered severe economic hardships that encompassed the different industries and were evident mainly in rising unemployment, particularly among the younger generation. These countries were ruled by despots, who managed to organize a life of wealth and liberty for themselves and their families while their subjects struggled to make a living (Anbarani, 2013).

Hence, the deteriorating economic situation stemming from the emerging global crisis (Sub- Prim) incited people's anger against the leadership and fomented the revolt, protesting both the severe financial

Institute for Economics \& Peace. Economic Consequences of War on the U.S Economy. Sydney-New York-Washington D.C. (2011). Institute for Economics \& Peace (IEP) has offices in Sydney, New York, and Washington, D.C. It works with a wide range of partners internationally and collaborates with intergovernmental organizations on measuring and communicating the economic value of peace.

5 World War II, the Korean War, the Vietnam War, the Cold War, and the wars in Afghanistan and Iraq.

6 Since the beginning of World War II in 1941 and until the years of conflict involving the United States in Afghanistan and Iraq during 2005-2013. 
and subsistence problems and the sociopolitical problems that spread and took root among the top leaders. ${ }^{7}$ Furthermore, the years that preceded the waves of revolt saw a rise in the global prices of grain and sugar due to the severe drought in the region, making it even harder for the destitute citizens of Arab countries to survive financially. But despite these tribulations the authorities showed no willingness to help (De Châtel , 2014). In fact, the years preceding the civil protests in the Arab world showed a trend of economic growth in several Arab countries despite the global crisis, although this growth had no effect on the common citizens as the economy in these countries was controlled by the economic and political elite, usually comprised of one very powerful family, who used it to serve their own interests (Feiler, 2013). Additionally, the economic growth did not proceed at the same rate as the increase in the labor force during those years, and this created rising unemployment, primarily among young intellectuals, and contributed to their frustration and animosity towards the authorities.

These circumstances stimulated the political catalysts of the "Arab Spring" protests, as civilian contempt for government corruption and abuse of state funds increased and led to great frustration and resentment, delegitimizing the regime (Cook, 2011) and creating a need to redefine local government (Bligh, 2014). Thereupon, a wave of protest began to spread among the various Arab countries, intensified by modern media that provided the young revolutionaries with a means of communication. Extensive was made of social networks such as Facebook and Twitter, which helped citizens overcome their fear of the authorities. Massive demonstrations by government opponents were organized through these media, encompassing several components: economic (such as the objection to unequal distribution of state funds), political (such as the fight against corruption), and psychological (such as the objection to abuse of human dignity and disrespect for human life).

This paper highlights events in Syria, with its major significance for the security and political stability of the sensitive Middle East region and its dominant role in the various events occurring there. Syrias "Arab Spring" indeed began with a civil uprising born from the optimism originating in Tunisia in late 2010, and in Egypt and Libya in early 2011. But in time it developed into an attempt by the rebel movement ("Free Syrian Army") to overthrow the regime and then to civil war, which further deteriorated to a state of all-out war once the forces of ISIS, Hizbollah, and Jabhat al-Nusra joined the battlefield, forming a real threat to Bashar al-Assad's continued rule.

Similar to other Arab countries, in Syria as well the civil uprising began as a result of a combination of political, ethnic, social, and economic factors. ${ }^{8}$ This uprising has significant and important implications and has generated much research. ${ }^{9}$ Some explored the implications of the events for the emergence of democracy in the Middle East in general and in Syria and Egypt in particular (Sarıhan, 2012) while others examined the future effect of the events on the roles and functioning of key actors in the international sphere, such as the League of Arab States (LAS), the United Nations Security Council (UNSC), NATO, etc, (Simpson,2011). Yet others expressed a true concern that the fighting in Syria in general and the involvement of ISIS in this fighting in particular might ignite an overall regional war in the Middle East (Stathis, 2015).

\footnotetext{
For example: unequal distribution of state revenues, intensification of corruption among top leaders, and restriction of individual liberties by the government.

8 In response to anti-social economic steps by the Syrian regime, such as cancellation of the subsidies and acceleration of liberalization in the early 2000 s.

9 For example: Erez Cohen, Global Quake - World's Economics Facing the Financial and Political Crises during 2008-2012, (Ariel: Ariel University Publishing, 2015), 158-160, 181-189.
} 


\section{CHANGES IN SYRIA'S ECONOMIC POLICY}

The neoliberal policy of the Syrian regime that began to emerge in the early 2000s, widening the socioeconomic gaps in the country and intensifying its housing problem (Goulden, 2011) as well as the dwindling economy and the low growth rate, are directly linked to the demonstrations against the regime that began in March 2011. These began as a small, quiet, popular civil protest (mainly in peripheral areas and in slums in major cities) in which the citizens called upon President Bashar al-Assad to act to enforce an economic reform but did not call for his resignation, in recognition of the Western image he had created for the country. Nonetheless, when their faith in Assad's ability to perform the necessary structural reforms waned (seeing that he made do with proposing several particularly superficial reforms), they began to step up the struggle and their resistance to Assad and his regime, (Phillips, 2012). This local protest was at first perceived by Assad as marginal, incomparable with the intense protests and uprisings spreading throughout the Arab world, as he believed in his own might and in the stability of his regime. Although the "Arab Spring" protests that led to the overthrowing of long-standing leaders in Tunisia and Egypt clearly had the effect of breaking the fear barrier in the Arab world in general and among Syrian citizens in particular, Assad's rule still appeared stronger and more stable than other Arab regimes subjected to such protests. This concept concerning the stability of the Syrian regime was based on several factors, both external and internal.

First of all, Assad's resolute and intransigent foreign policy objecting to the United States and Israel earned him the legitimization of Arab countries and therefore he was inclined to believe that he would enjoy the support of these countries in case of a real threat. Secondly, the fate of Syrian army and security personnel was strongly linked to that of Assad's regime; therefore, they expressed no resistance to his political leadership, rather displaying their loyalty and even leading the policy of cruel and violent repression of the demonstrators (unlike the situation in Tunisia and Egypt, where some of the local security forces sided with the protestors). Moreover, the Syrian regime chose to utilize the most loyal military divisions, comprised mainly of the Alawite minority, as Assad himself is of Alawite background (Kelidar, 1974 ; Zisser, 2003). Third, the stability of Assad's regime was also accounted for by the fact that he leads a relatively modest life, strives to maintain the country's unity, and has led it to economic growth while implementing considerable economic and social reforms. Fourth, the Syrian opposition was not well coordinated or united and it was often divided, with no single declared and accepted leader.

However, the many factors allegedly capable of sustaining the stability of the Syrian regime did not manage to prevent the emergence of Syria's protest movement or to dispense with it once it grew and spread throughout the country. Assad's internal policy, with its repression of civil rights, aroused much frustration among local citizens and particularly among the young, who were now willing to openly oppose the military and the security forces and to confront them. In response, Assad instructed his forces to act forcibly against the rioters and even to make use of live fire, and he allowed them unrestricted license and leeway in order to guarantee the stability of the government (Zisser , 2014).

The security forces did not hesitate to apply these instructions in full force in early February 2011 against demonstrators in the southern city of Derra, a response that backfired as the protest proceeded to spread throughout the country. The Syrian security mechanisms were so powerful that the situation quickly spiraled out of control once they descended to acts of torture and displays of cruelty that earned Assad's regime the reputation of a despotic government that should be eliminated as quickly as possible for moral reasons (Lesch, 2011). This radical response of the authorities to the demonstrators changed the goals of the protest and the protestors, morally encouraged by the success of the revolutionary wave within the Arab world, began to openly call for Assad's resignation. Once Assad became aware that the protest against him was growing he instructed his army to deploy throughout the country in order to repress the uprising, using 
considerable power bordering on torture, unrestrained shootings and bombings, and even chemical weapons. In this way, what had begun as a quiet protest was rapidly transformed into an uncontrollable all-out war. The Arab League and UN forces attempted to arrange a ceasefire between the rebel forces and Assad's army, acting to promote negotiations between the rivals with the aim of establishing a national government that would supervise the actions of the Syrian regime. As they saw it, only such a compromise could preventing Syria's demolishment, as rebuilding the country would take one or two generations (Seale, 2012) . Nonetheless, despite their many efforts the hoped-for compromise did not materialize and the savage fighting continues, claiming the lives of hundreds of thousands, both civilians and soldiers.

As the fighting continued, more Syrian soldiers gradually deserted to the rebel forces ("Free Syrian Army") and the disorder within the country grew. Army deserters initiated an armed struggle against the Syrian army and, as a consequence, led the country to a full blown civil war, (Erickson, 2013). Still, Assad's regime remained stable, and similar to Mubarak in Egypt he was supported by the elites (the rich, politicians, business people, and military leaders). Moreover, many Syrian citizens avoided openly supporting the rebels and opposing Assad's regime for fear of the Syrian army's violent response to such acts of support. At the same time, several international organizations (such as the Arab League and the European Union) imposed economic and diplomatic sanctions against Assad's government and demanded his immediate resignation. However, at present these external pressures seem incapable of overthrowing Assad's regime and leading to a real revolution in Syria (Sarıhan, 2012). As these words are being written, fighting in Syria has not yet reached its conclusion. The country is in a state of total chaos and the death count is climbing daily and is the highest among all "Arab Spring" protests. Whatever the eventual result of this recalcitrant conflict, it is already evident to everyone that rehabilitating the domestic economy, finding a solution to the housing crisis, and reducing economic inequality in Syrian society will constitute a challenge for Assad's government or for any other government that will replace it once the fighting dies down, (Goulden, 2011).

Political and economic developments in the Middle East in general and in Syria in particular have generated extensive research and many publications (Kedourie, 2013). Some have reviewed and examined different periods in the short history of this state, since its establishment in $1941^{10}$ and even previously (Kelly, 2012). At the same time, in order to further stress the differences in Syria's economy before and after the fighting erupted, as this paper aims to do, the current discussion shall focus on the economic sphere. For this purpose, a short review of Syria's economic policy shall be presented, from the mid-twentieth century to the beginning of the brutal events in early 2011.

A review of Syria's economic development shows that over the years this economy showed relatively high growth levels, particularly in the 1960s and 1970s. In these decades, Syria's gross domestic product grew considerably, at a rate that sometimes reached double-digit figures ${ }^{11}$ (although in some isolated years the GDP was in decline ${ }^{12}$ ). These years were characterized by economic and social progress termed "Arab socialism" and promoted by the Syrian leadership, which emphasized basic civil services and decentralized development of infrastructure throughout the country (Perthes, 1992). However, in the 1980s Syria encountered economic problems resulting primarily from the policy of strategic development implemented by the Syrian government a decade earlier and less from external factors. These problems continued until the end of the decade, and required the Syrian leadership to accelerate processes of liberalization in order to sustain economic development (Hinnebusch, 1997). As a result, in these years Syrian economic growth

10 At the same time, only in 1944 was it recognized as an independent republic.

${ }_{11}$ In 1961 Syria's GDP grew by 10.8 percent, in 1969 by 18.7 percent, in 1972 by 25 percent (!), in 1974 by 24.1 percent, in 1975 by 19.5 percent, and in 1976 by approximately 11 percent (Source: World Bank database).

12 In 1963 Syria’s GDP declined by 8.6 percent, in 1966 by 7.6 percent, in 1973 by 8.5 percent, and in 1977 by 1.2 percent (Source: World Bank database). 
diminished, ${ }^{13}$ while at the same time the involvement of the leadership in domestic economic activity decreased as well, making it possible to expand neoliberal reforms and to increase socioeconomic inequality in the Syrian economy, manifested in growing housing problems among Syrian society. At the same time, the political corruption typical of the Syrian government in previous decades remained rampant and sometimes even worsened, undermining the Syrian government's previous image as an emblem of social solidarity and socioeconomic justice (Goulden, 2011).

The collapse of European communist regimes in the early 1990s and the bitter fate of the Soviet Union was not reflected in the fate of the Syrian government in these years, despite their similarities. The latter remained stable both politically and economically, mainly thanks to the country's abundant oil resources. The high revenues generated by the sale of oil in the 1990s, when it became the country's leading export industry that reached its height in the middle of this decade, ${ }^{14}$ aided Syria's economic survival and facilitated its continued economic stability. In the 1990s the Syrian economy continued to grow at a fast pace, particularly during the first half of the decade, when its GDP grew at an average annual rate of 8 percent. ${ }^{15}$

The beginning of the new millennium brought with it no good tidings for the Syrian economy in general and its oil industry in particular, as in the early 2000s the capacity of the local refineries began to dwindle, as did its oil reserves. Furthermore, in these years the price of oil dropped considerably, with a consequent impact on the profitability of this industry for the domestic economy. Moreover, the drop in the price of oil was a blow to the Gulf States as well, and in response they proceeded to cut down on the assistance and loans previously granted to Syria. Thus, the harm to the country's economy in these years was particularly tangible and conspicuous and it was evident in the GDP indicator, which reflected the considerable drop in the economy's growth rate. ${ }^{16}$ From this respect, the Syrian regime confronted the same dilemma as communist regimes in Europe before their collapse: whether to boost the economy by liberalization processes such as privatization, removal of supervision, and bringing foreign investors into the country, or maintain their totalitarian rule and not endanger it by implementing reforms that might threaten the stability of the government (Cohen, 2015).

The ascension of the current president, Bashar al-Assad, to power on July 17, 2000, boded well for the local economy. As early as his first inauguration speech Bashar criticized the former policy instituted during the reign of his father Hafez al-Assad, offering his own ideas of how Syria could be promoted from an economic standpoint by instituting a technological reform and pushing processes of democratization and modernization. His words aroused some hope that the new policy would change the country's direction and integrate it in the modern western world. Indeed, during Bashar's first months in power the Syrian regime was characterized by relatively open relations, and it even coined the term "Damascus Spring". During this period, which lasted more than eight months, general pardons were granted to political prisoners from all organizations, privately owned newspapers were allowed to operate, the government-controlled media was regenerated, critical institutions were given freedom of action and treated tolerantly, and the policy of personality worship typical of the previous regime was cancelled (Malovany, 2014).

13 Aside from the first years of the decade, 1980 and 1981, when the GDP grew at a particularly high rate $(12 \%$ and $9.5 \%$, respectively).

${ }^{14}$ In 1995 Syria's oil output reached a height of 580 thousand barrels per day.

15 In the first years of the 1990s until the middle of the decade, Syria's GDP grew at a fast pace: In 1990 the GDP grew by 7.64 percent, in 1991 by 7.9 percent, in 1992 by 13.47 percent, in 1993 by 5.17 percent, in 1994 by 7.65 percent, and in 1995 by 5.75 percent (Source: World Bank database).

16 For example, in 2000 Syria's GDP grew by 2.7 percent, a relatively low rate compared to the growth levels typical of the domestic economy in the previous decade. 
Bashar al-Assad's regime indeed declared a plan of economic openness ${ }^{17}$ ("Infitah"), however in practice it did not promote any significant course of action in this direction rather continued to limit the Syrian economy's acceptance of the free world, both economically and with regard to the flow of information to and from the country, by further restricting citizens' access to the global internet network (Zisser. 2006). This policy of the Syrian leadership, which chose to preserve the totalitarian regime and to leave Syria in its old-fashioned state, closed to the world and technologically primitive, aroused the rage of its citizens, who in 2011 began to protest against the government, although due to the might of the Syrian government only few predicted that this angry protest would lead to a civil uprising. In the knowledge that popular uprisings had helped overthrow the dictator regimes of Tunisia and Egypt, the Syrian protestors were encouraged and accelerated the protest, which rapidly took the form of a brutal civil war (Seale, 2012).

The claim that the civil war in Syria, intensified by the addition of ISIS, Jabhat al-Nusra, Hizbollah, and other forces, is crushing the foundations of the Syrian regime and threatening the continued existence of the state in its current form, is well known. But what are the economic implications of this war? What are its effects on the different components of the GDP and on the unemployment indicator of the Syrian economy? These issues are explored and portrayed below.

\section{SYRIA'S ECONOMIC INDICES DURING THE ARAB SPRING}

The switch from Hafez the father to Bashar the son in 2000 had no particular effect on Syrian GDP indicators in the first decade of the 2000s, and in these years the Syrian economy continued to consistently show stable growth at an average rate of approximately 5 percent, despite the global financial crisis of 20082009. However, the outbreak of the riots in Syria in 2011, which as stated shook the country's government, seems to have left its mark on the domestic economy which in this year began to show signs of a recession $(-3.7 \%)$ after a long period of growth and economic stability. The decline in Syria's GDP became acute in $2012(-18.8 \%)$, reflecting the country's severe economic deterioration (Nasser, 2013).

The sharp decline in Syria's GDP in 2012 was examined by the Syrian Centre for Policy Research (SCPR) ${ }^{18}$ which showed its negative effect on the various domestic industries ${ }^{19}$ and determined that in this year Syria's wholesale and retail trade sector, including restaurants and hotels, had suffered the most from contraction of the GDP. This was a result of the heavy blow to the tourism industry, the decline in demands for services and commodities, problems with the supply chain, rising inflation, devaluation of the Syrian pound, travel restrictions on people and commodities, and the general feeling of economic insecurity with its negative impact on aggregate consumption. ${ }^{20}$

The conspicuous decline in the GDP in 2012 is explained by the sharp drop in all GDP components: a sharp 75 percent reduction in public consumption, a considerable 81 percent drop in private consumption, a considerable decline in foreign investments, the flight of large amounts of foreign capital, ${ }^{21}$ and the slowing down of foreign trade. ${ }^{22}$ In addition, in 2011-2012 public expenditures in Syria rose considerably

\footnotetext{
17 The Syrian regime also brought Syrian exiles from the west to promote economic reforms, but it later became evident that this was only for the sake of appearances. As a result, most of the exiles resigned in frustration after a short while.

18 Syrian Centre for Policy Research for the United Nations Relief and Works Agency (UNRWA), Syria - The Syrian Catastrophe: socioeconomic monitoring report. First quarterly report (January - March 2013).

19 Ibid, p. 9. Table 1: GDP by sector 2010-2013-Q1 and estimated crisis impact, billions of SYP (in constant 2000 prices).

20 Ibid, p. 8.

${ }^{21}$ During 2011-2012 the incredible amount of 84.4 billion dollars exited Syria's borders (equaling 142\% of the GDP in 2010).

22 Exports declined by 75 percent and imports by 60 percent.
} 
and were channeled mainly towards military causes ${ }^{23}$ and rehabilitation of the damages resulting from the devastation and looting, ${ }^{24}$ leading to considerable economic losses to the state's coffers and deceleration of Syria's economic activities. ${ }^{25}$ These years also saw a considerable drop in foreign currency balances ${ }^{26}$ and in the country's revenues from taxes and from the oil industry, which was hard hit by the economic sanctions imposed on the country (mainly by European Union countries). See Figure 1 which describes the changes in Syria’s GDP indicators during 2000-2012.

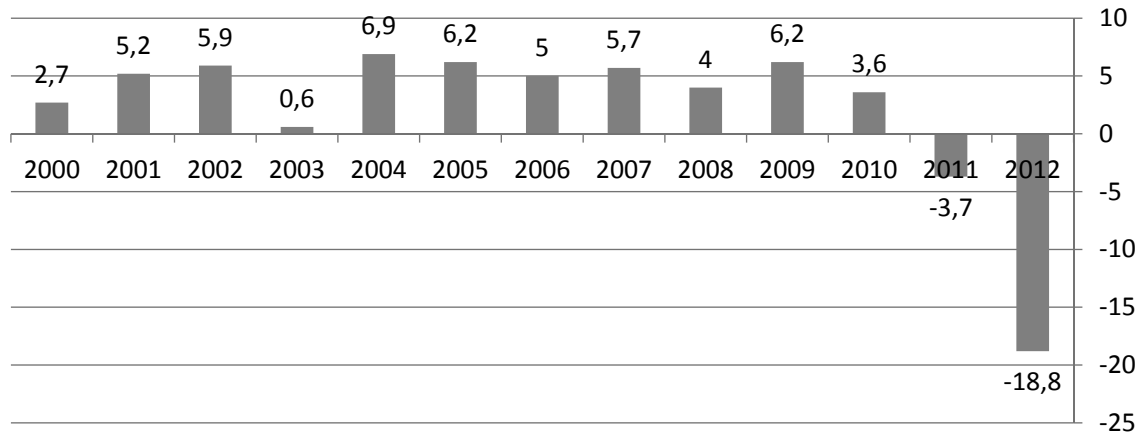

Figure 1: Syria's Total GDP, 2000-2012 (annual \%)

Source: GDP figures for 2000-2012 were taken from the World Bank website: http://databank.worldbank.org/data/ home.aspx; GDP figures for 2013 and 2014 were taken from the SCPR website: http://scpr-syria.org/en/ Subjects/T9/Projects.

As these words are being written, Syrian GDP figures for 2013 and 2014 are not yet accessible in international databases and on the World Bank website, however the latter reports that since 2012 the estimates differ, with the EIU (Economist Intelligence Unit) offering a more optimistic perspective than the SCPR (Syrian Centre for Policy Research) and the ESCWA (Economic and Social Commission for Western Asia). The SCPR and the ESCWA converge in their projection that economic contractions significantly slowed in 2014, with the GDP falling to 38 percent (SCPR) or 48 percent of the 2010 GDP (ESCWA). The EIU, on the other hand, projects that the economy has bottomed out, with growth averaging a modest 0.5 percent in 2014, driven by the economy's adjustment to the military stalemate in addition to the considerable migration of businesses to more stable coastal areas. That as it may be, it seems that there is no dispute as to the negative impact of the civil war in Syria on the Syrian GDP in 2014.

Syria's GDP remains dependent on the oil and agriculture sectors, themselves subject to fluctuating oil prices and rainfall. Main sources of foreign earnings were previously oil exports, exports of services, and foreign transfers of income and remittances; however, these sources are now seriously curtailed by the crisis ${ }^{27}$. Furthermore, some of the oil reserves are currently in the hands of resistance forces, such as the large oil reserve in Deir ez-Zur controlled at present by ISIS.

23 Reached a total of 4.85 billion dollars.

24 Estimated damage of 41.2 billion dollars.

25 As presented below in Table 1.

${ }^{26}$ From a balance of 23 billion dollars in 2010 before the riots broke out to a balance of only 2 billion dollars two years later, in 2012 .

27 http://www.worldbank.org/en/country/syria/overview 
In addition, the conflict has caused a decline in government revenues and a spike in spending, sending the fiscal balance into severe deficit. ESCWA estimates a 2013 budget deficit of -26.3 percent of the GDP. EIU estimates a deficit of -12.9 percent in 2013 and projects deficits of -10.7 percent of the GDP in 2014. SCPR estimates a deficit of close to 20 percent during 2013 and 2014 and almost doubles its estimates to 35.7 percent and 40.5 percent after adding off-budget subsidies. SCPR projects that foreign debt increased tenfold from 7 percent of the GDP in 2010 to 71 percent by the end of 2014, whereas domestic debt increased from 16 to 76 percent of the GDP. This implies a total debt of 147 percent of the GDP by the end of 2014. Meanwhile, the EIU estimates the external debt in 2014 at a much lower 40 percent of the GDP. ${ }^{28}$

In addition to the decline in GDP figures, the unemployment indicator as well indicates an aggravation in the deteriorating Syrian economy during the years of conflict. Syrian unemployment levels rose significantly in a short period, among other things due to bombings that paralyzed and even destroyed many factories and workshops (mainly in the cites of Aleppo and Damascus), creating millions of unemployed, and also as a result of the sharp drop in demands for commodities and services in these years. The rise in Syrian unemployment rates was gradual but very conspicuous: from a relatively moderate rate of 8.4 percent in 2010, unemployment in the domestic economy reached some 15 percent in 2011. However, the continued intensified fighting caused a further deterioration of Syria's job market in 2012, and unemployment rates reached approximately 35 percent. ${ }^{29}$ UNRA figures (United National Development Programs) ${ }^{30}$ present an even more dire picture and show that during 2013 and 2014 over half Syriass workforce joined the ranks of the unemployed, ${ }^{31}$ as evident from Figure 2.

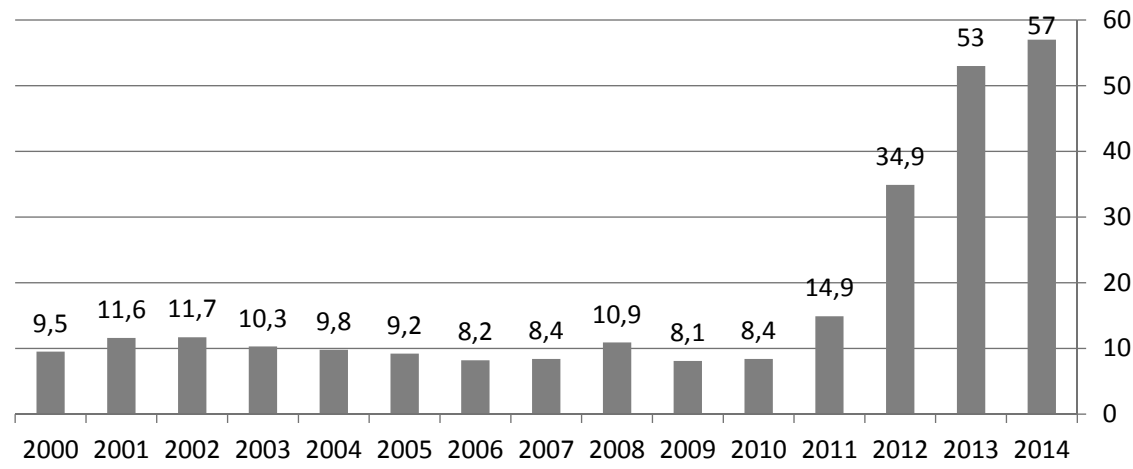

Figure 2: Syria's Total Unemployment, 2000-2014 (annual \%)

Source: Unemployment figures for 2000-2010 were taken from the World Bank website: http://databank.worldbank. org/data/home.aspx; Unemployment figures for 2011-2014 were taken from the SCPR website: http://scprsyria.org/en/Subjects/T9/Projects.

\footnotetext{
28 http://www.worldbank.org/en/country/syria/overview

29 According to SCPR figures.

30 http://www.undp.org

31 UNRA, Syria-Alienation and Violence. Impact of Syria Crisis Report 2014. (March, 2015), p. 34. http://www.unrwa.org/sites/ default/files/alienation_and_violence_impact_of_the_syria_crisis_in_2014_eng.pdf
} 
The impact of the war on GDP growth and on unemployment rates is only one part of the picture, as a no less significant consideration is its effect on capital investments. It is only reasonable that a country in a state of security and government chaos is not attractive to foreign investors, tourists, and business owners. Moreover, this state of affairs can lead to the halting of projects and the withdrawal of investments, as indeed occurred in Syria in these years. Data published by the SCPR reveal that since 2010 and until the first quarter of 2013 the Syrian economy lost an incredible sum of 84.4 billion dollars (equal to 142 percent of the economy's total GDP in 2010). Many sectors in the Syrian economy have suffered and are still suffering from a lack of demand, uncertain stability, and even international sanctions (such as the tourism and mining industries). ${ }^{32}$

Another important indicator that has been hard hit as a result of the fighting is export, which dropped by nearly 50 percent in 2012 compared to the previous year, ${ }^{33}$ mainly as a result of the sharp drop in oil exports (See Figure 3).

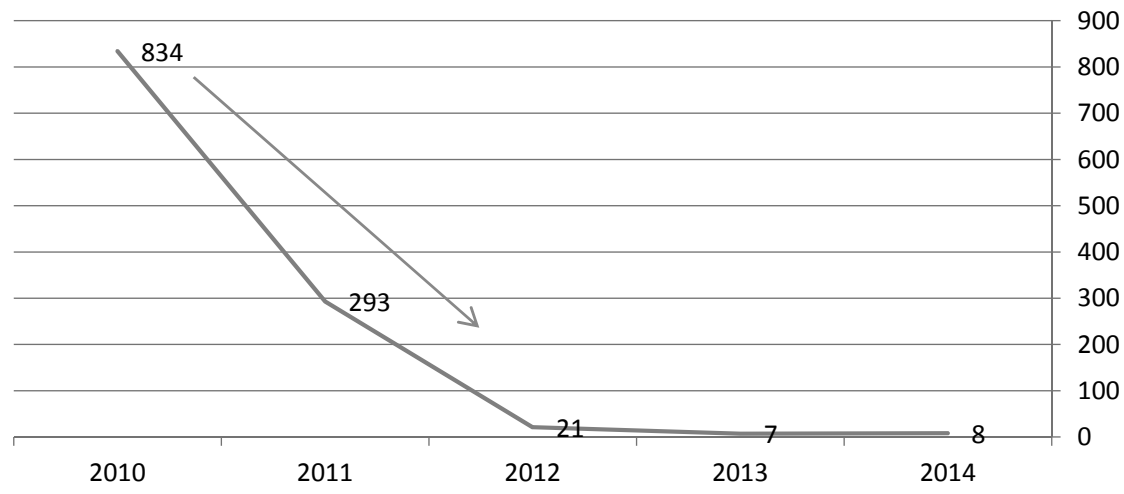

Figure 3: Syrian's Fuel Exports, 2010-2014 (Millions of Euros)

Source: European Commission website: http://trade.ec.europa.eu/doclib/docs/2006/september/tradoc_111615.pdf.

The drop in Syria's total exports had a severe effect on the country's balance of trade and reflected the excessive exposure of the domestic economy to foreign economies, while also emphasizing its considerable dependence on imports, made possible mainly by foreign loans. This state of affairs has led to a deficit in the country's balance of payments and is creating an uncontrollable debt for the next generation (see Figure 4).

Another aspect of the financial blow to the Syrian economy as a result of the continuous fighting is the increase in military expenditures, ${ }^{34}$ usually at the expense of allocations for public causes (such as education, health, and welfare). Redirecting funds from productive to non-productive processes and sometimes to destructive military purposes harms citizens' quality of life while also leading to overall economic decline (Nasser, 2013). Table 1 presents the country's revenues versus its expenditures during 2010-2014 and highlights the rise in the budgetary deficit.

32 Syrian Centre for Policy Research for the United Nations Relief and Works Agency (UNRWA), Syria- The Syrian Catastrophe: socioeconomic monitoring report. First quarterly report (January - March 2013). Figure 3: Estimated loss 2010-2013-Q1 of Capital Stock, millions of USD in current prices, p. 15.

33 Syrian Centre for Policy Research for the United Nations Relief and Works Agency (UNRWA), Ibid, p. 15.

34 At a rate of 2.2 percent and 8.8 percent of the total GDP in 2011 and 2012, respectively. Source: Ibid., SCPR, 2013. 


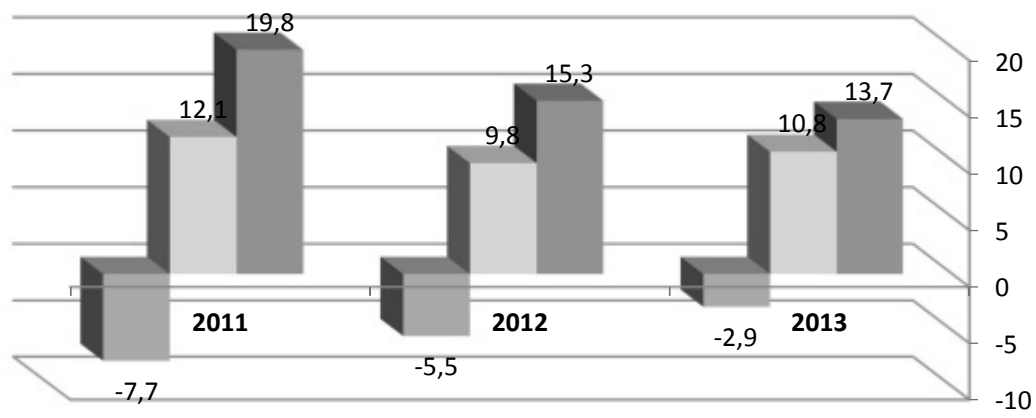

- Import Export $\square$ Balance

Figure 4: Syrian's Trade Balance in the years 2011-2013 (Millions of Euros)

Source: IMF (Direction of Trade Statistics).

Table 1

Revenues, Expenditures, and Government Budget Deficit (\% of GDP), 2010-2014

\begin{tabular}{|l|c|c|c|c|c|}
\hline & 2010 & 2011 & 2012 & 2013 & 2014 \\
\hline Revenues & 22.7 & 17.3 & 10.4 & 7.2 & 6.2 \\
\hline Expenditures & 24.9 & 26.3 & 26.6 & 27.1 & 27.2 \\
\hline Budget Balance & $2.2-$ & $8.9-$ & $16.2-$ & $19.8-$ & $21.0-$ \\
\hline
\end{tabular}

Source: UNRA (March, 2015). Ibid, p. 30.

Indeed, Syria's drawn-out civil war seems to have had a severe effect on the local economy, causing the GDP to decline and to change its structure ${ }^{35}$ and deepening the budget deficit. While Syria's official economy is failing, however, an unofficial economy has emerged, consisting of a black market as well as criminal and violent elements, which might impede future possibilities of rehabilitating the economy once the fighting ends and the conflict is resolved. It is also likely that the lengthy civil war will harm the country's economy even further, both as a result of the natural internal paralysis of economic activities in the warridden country and of the economic sanctions and growing international isolation of Syria and of Bashar's regime. Nonetheless, it would be interesting to examine the findings presented above (which, as stated, indicate the destructive effect of Syria's civil war on its economic indicators) in comparison to other countries in the Middle East that have experienced political and security chaos in recent years as well.

\section{COMPARISON TO OTHER ARAB COUNTRIES}

Although the Arab Spring protests also spread to Tunisia, Algeria, Jordan, Morocco, Iraq, and Oman, the following comparative review shall focus on Libya and Egypt. Unlike the protests in the former countries, which were manifested in large stormy demonstrations but did not manage to topple the government,

35 On one hand, a drop in private consumption, investments, and exports; on the other, a rise in public expenditures, mainly for military purposes. 
the protests in Libya, Egypt, and Syria developed into actual civil wars characterized by savage fighting and complex political situations and therefore they serve as a basis for comparison as presented below. The GDP and unemployment figures for Egypt, Libya, and Syria during 2007-2014 are presented in Tables 2 and 3, respectively:

Table 2

Total GDP of Syria, Egypt, and Libya, 2007-2014 (annual \%)

\begin{tabular}{|c|c|c|c|}
\hline & Syria & Egypt & Libya \\
\hline 2007 & 5.7 & 7.1 & 6.4 \\
\hline 2008 & 4 & 7.2 & 2.7 \\
\hline 2009 & 6.2 & 4.7 & $0.8-$ \\
\hline 2010 & 3.6 & 5.1 & 5 \\
\hline 2011 & $3.7-$ & 1.8 & 104.5 \\
\hline 2012 & $18.8-$ & 2.2 & $13.6-$ \\
\hline 2013 & Not Viable & 2.1 & $24-$ \\
\hline 2014 & Not Viable & 2.2 & \\
\hline
\end{tabular}

Source: GDP figures are from the World Bank website, aside from data on Syria's GDP for 2013-2014, which is from the CPR website.

Table 3

Total Unemployment in Syria, Egypt, and Libya, 2007-2014 (annual \%)

\begin{tabular}{|c|c|c|c|}
\hline & Syria & Egypt & Libya \\
\hline 2007 & 8.4 & 8.9 & 19.4 \\
\hline 2008 & 10.9 & 8.7 & 19.1 \\
\hline 2009 & 8.1 & 9.4 & 18.9 \\
\hline 2010 & 8.4 & 9.0 & 18.2 \\
\hline 2011 & 14.9 & 12.0 & 19.6 \\
\hline 2012 & 34.9 & 12.7 & 19.6 \\
\hline 2013 & 53.0 & 12.7 & 30.0 \\
\hline 2014 & 57.0 & 13.0 & 0 \\
\hline
\end{tabular}

Source: Unemployment figures are from the World Bank website, aside from data on Syria's unemployment for 2011-2014, which is from the SCPR website, the figures for Egypt's unemployment for 2014 from the Global Finance website: https://www.gfmag.com/global-data/country-data/libya-gdp-country-report and the figures for Libya's unemployment, from the Central Intelligence Agency website: https://www.cia.gov/library/publications/ the-world-factbook/geos/ly.html

The data presented in Table 2 show that the three countries experienced periods of growth in the years preceding the events. However, unlike the economies of Syria and Libya, Egypt's economy remained stable even after these began. Egypt, which experienced years of political instability (and has still not reached complete stability) continued to present positive growth figures even after the riots died down, although at a considerably lower rate than previously. In contrast, Syria and Libya entered a state of economic turmoil side by side with the political chaos, although the decline in the Libyan GDP in 2011 was more conspicuous than that of the 
Syrian GDP for that year. Then again, once the riots in Libya died down in 2012, its GDP resumed a course of growth and in 2012 it grew, as stated, at a very impressive rate. Syria, however, is still in a state of civil war with a destructive effect on its economy, which is unable to recover and is showing worrying levels of recession. The concern about the Syrian economy's low chances of recovery also stems from the fear that Syria will lose its sovereignty and will become a split and divided country rather than a recognized and legitimate sovereign state, possibly removing it from the map of global trade and leading to political and economic annihilation.

The figures in Table 3 show unemployment rates in the three countries in the period preceding the events and subsequently, indicating similar trends to those evident in the previous table. The Egyptian economy is the most stable of the three and although since 2011 unemployment has risen considerably it is still low compared to Libya and Syria. Unemployment in Libya was relatively high before the riots broke out (about 20 percent). In 2010 and 2011 there was a positive shift in this indicator and it began to drop slightly and reached about 18 percent in 2011, however the security deterioration in this year left its mark on the local job market and in 2012 unemployment rose once again, reaching about 20 percent and even more the next year (30\%). In contrast, the Syrian economy enjoyed relatively low unemployment rates prior to the fighting (during 2009-2010), however only three years later it had deteriorated rapidly and sharply to inconceivable rates of more than 50 percent (during 2013-2014: 53\% and 57\%, respectively).

\section{DISCUSSION AND CONCLUSIONS}

Hence, the research findings indicate that Syria is going through a very tough "economic winter" and that the civil war has had a considerable negative effect on domestic economic indicators, both in absolute terms and compared to other Arab countries such as Egypt and Libya, which also experienced internal conflicts and governmental chaos. These findings corroborate the many studies that link the reality of war to a considerable decline of GDP and unemployment indicators and disprove studies that attest to the positive effect of war on economic activities as a result of the rise in government expenditures and particularly defense expenditures. The findings presented in this paper indicate a considerable negative effect on the GDP (resulting from the consumer paralysis in the Syrian economy during the war years, the drop in foreign investments, and the considerable decline in Syrian exports and particularly oil exports) as well as the impact of the civil war on unemployment rates, which have reached particularly high levels.

There is indeed much evidence of economies that had been in a state of economic crisis due to war and managed to recover very rapidly after it ended, both by means of GDP growth and by a drop in unemployment (for example, the Israeli economy after the Six Day War). The case of Syria, however, is different as the continuous war in Syria leads to uncontrollable political and security chaos that is increasing levels of uncertainty and doubts as to the country's survival and has hence accelerated the negative impact on domestic economic indicators. Moreover, the economic sanctions imposed on Syria in response to the violent acts of the Syrian regime against its opponents are further aggravating the country's economic recession.

Analyzing the impact of the war in Syria on its economic indicators presented in this article, stresses the necessity for a mediating element in order to create a positive connection between conclusion of the fighting and accelerated economic recovery. This mediator is international economic activity that constitutes a necessary condition for the economy's extraction and recovery after a period of war. The rapid economic recovery of countries that have experienced war is facilitated by a free market (whether full or partial) that provides the basic conditions for efficient international economic activity. The rapid growth of a country that experienced war depends mainly on international economic activity rather than on domestic economic activity. In this context, notable examples are the rapid growth of Israel's economy after the conclusion of the Six Day War in 1967, the 
international economic activity enacted in Libya with the aim of accelerating its growth after the conclusion of hostilities in 2012, and the considerable improvement in Afghanistan's economic indices, several years after the United States entered the land to fight the Taliban forces and Al Kaida, thanks to the presence of international peace keeping forces as well as the external aid that contributed (respectively) to the political and economic stability of this country ((Goodhand, 2004; Johnson, Maley, Their \& Wirdak, 2003). Moreover, when the economic aid was terminated and the international forces began to retreat from the country, a negative effect on the flow of foreign investments was evident, as it began to recede and local economic indices were affected ${ }^{36}$.

It appears, however, that several conditions must exist in order to facilitate an increase in this international economic activity: first of all, the existence of sellers (e.g., heads of state, business owners, and companies) and buyers (foreign countries, foreign investors, etc.). Secondly, some type of a liberal trade environment that enables international deals. Third, an optimistic perspective concerning the future of the country despite the considerable physical and economic destruction wrought by the war.

Syria's economy does not satisfy any of these conditions: First of all, there is a buyers and sellers limitation: The lengthy and brutal civil war in Syria is undermining the foundations of the government and its stability and raising many doubts as to who has sovereignty over the country's economy in general and its economic assets in particular. This state of affairs makes it hard to identify sellers, as the country has no real stable long-term sovereign, raising major doubts and concerns for potential buyers who are reluctant to risk their money and invest in a disintegrating country. Secondly, the trade environment is artificially limited and does not enable natural free international deals (even if there was no problem involving the buyers and sellers). The limitations on free trade with Syria were generated by the severe sanctions imposed by international organizations. These will probably not be removed once the hostilities end, as it is quite possible that if and when Assad's deplorable rule is replaced by another the latter will be characterized by radical Islamic nationalism (such as ISIS, Jabhat al-Nusra, Hizbollah, etc.) and will not lead to removal of the international sanctions in the near future. In this way, the international sanctions rule out the second condition required for the rapid growth of an economy following a war. And third, as in a deal on the free market, investors and buyers are motivated and urged to invest in or purchase a product or company in crisis by their real concept of the relatively low price of the product or company (resulting from the crisis experienced by the company or country), together with their optimism as to the future recovery chances of the product or company. This optimism lets the investor or buyer identify the crisis-ridden market as a one-time opportunity that presents short-term financial risk, in the belief that this investment will pay off in the long term. However, in Syria's case this condition as well does not exist, as there are considerable doubts and pessimism as to Syria's political and economic future, significantly reducing the attractiveness of investment opportunities.

Syria's economy is disintegrating both externally and internally. On one hand, it is slowly becoming irrelevant for global trade in general and for the oil industry in particular and is losing its place to competitors in this field. Then again, it is coping with internal socioeconomic problems, since economic destruction has engendered drastic levels of inequality and inequity as the domestic economy fragmented across the country, where armed parties created an irregular situation in order to control and rule institutions and resources. To retain their dominance, the different parties have reallocated resources to create incentives and loyalty among their followers.

There are indeed many doubts as to Syria's ability to survive this shaky period and restabilize its regime as a united and stabled state, as in addition to the physical and financial destruction Syria is also dealing with the mass migration of citizens (almost all from the Suni sect), which will probably affect the ethnic balance (of Sunis versus Alawites) and make it harder to stabilize the government (Khater, 2005). ${ }^{37}$ In addition, such

36 GDP: 2013: 2\%, 2014: 1.3\%. Unemployment: 2013: 9.2 , 2014:9.1\%. Source: World Bank : http://databank.worldbank.org/data.

37 Migration of citizens from Syria occurred in the past to America, as analyzed in Khater's article: Khater A. Becoming "Syrian" in America: A global geography of ethnicity and nation. Journal of Transnational Studies, 14 (2005):299-331. 
mass migration will further harm the country's economy, as the exit of such a large work force will have a serious detrimental effect on the local economy's production capacity and consumption force.

However even the optimists understand that the challenges facing the government if and when the situation stabilizes are particularly manifold and difficult, as together with the need to cope with immediate economic challenges, Syria will also need to support the return of internally displaced people and refugees in neighboring countries, rebuild the country's physical and economic infrastructure, enhance the provision of public services including health and education, and rebuild the country's social fabric. Predictions and forecasts for the future might indeed prove to be exaggerated or even mistaken in retrospect, as it is not inevitable that Asad's allies, Russia and Iran, that are assisting him at present from the military point of view, will extend their support to the economic arena, help him rehabilitate the disintegrating economy, and constitute a major force in its future recovery. Furthermore, the severe terror attacks perpetrated in France in November 2015 by ISIS have led to a change in attitude of European countries, primarily France, who previously objected to Asad's continued rule and now support Russia and Iran's attempts to stabilize Asad's rule, if only to prevent the victory of the brutal terror organization ISIS that wishes to take control of Syria.

This conclusion further clarifies the claim regarding the centrality and major effect of an external factor on the chances of a post-war country to recover and stabilize economically. As stated, such a factor, exemplified by the entrance of foreign investors, the benevolence of international institutions, organizations, and aid funds, or the activity of countries with a political and economy stake in the recovery of the affected country (in this case), would be capable of assisting in the financial rehabilitation of the country and returning it to a course of growth and prosperity. In the case of Syria, it seems that its slight chances of recovering economically depend mainly (or even exclusively) on the future willingness of Russia and Iran, countries with a political-economic stake in the Middle East, to extend the aid provided from merely security oriented to wide economic aid capable of helping rehabilitate the economy and stabilize its regime. However, if this scenario shall not come about Syria might dwindle both politically and economically until its complete extinction as a viable country.

In conclusion, the events of Syria's Arab Spring, whose initial emergence had economic roots as well, led to a civil war with political characteristics that has had a harsh effect on the local economy. The recovery chances of the local economy from the current crisis depend mainly on international political factors with an economic stake. Thus, no such doubts exist with regard to the importance and centrality of the political element for the relationship between war and economy as presented in this paper.

\section{REFERENCE}

Anderson, L. (2011), Demystifying the Arab spring. Foreign Affairs 90.3, 2-7.

Anbarani, A. (2013), Typology of Political Regimes in North Africa before Arab Spring

Case Study of Egypt, Tunisia and Libya. International Journal of Asian Social Science

3.5, 1089-1096.

Bligh, A. (2014), Redefining the post-nation-state emergence phase in the Middle East in Light of the "Arab Spring". The Journal of the Middle East and Africa 5.3, 201-219.

Baker, D. (2007), The economic impact of the Iraq war and higher military spending. Center for Economic and Policy Research, May.

Boskin, J. and Lawrence J. (1990), Post-war economic growth in the group-of-five countries: A new analysis. No. w3521. National Bureau of Economic Research. 
Bowen-Jones, H. (2013), Development in the middle east, in J.I. Clarke and H. Bowen-Jones (eds.), Change and Development in the Middle East, 3-23.

Castles, G. (1999), Decentralization and the post-war political economy. European Journal of Political Research 36.1, 27-53.

Cohen, E. (2015), Global Quake- World's Economics Facing the Financial and Political Crises During 2008-2012. Ariel: Ariel University publishing. 158-160; 181-189.

Cohen, E. (2014), The effect of advance industry on the resilience of the economy during war-the Israeli hi-tech industry as a case study. Journal of International Studies 7.2, 9-24.

Collier, P. (1999), On the economic consequences of civil war. Oxford Economic Papers 51.1, 168-183.

Cook, D. (2011), "The arab spring and failed political legitimacy. Hedgehog Review 13.3, 37-46.

De Châtel, F. (2014), The role of drought and climate change in the Syrian uprising: Untangling the triggers of the revolution. Middle Eastern Studies 50.4, 521-535.

Feiler, G. (2013), The economic repercussions of the Arab Spring. In: A, amber. (Editor). Arab spring? Israel, world and regional changes. Tel Aviv: IQ :161-167.

Fromkin, D. (2001), A peace to end all peace: The fall of the Ottoman Empire and the creation of the modern Middle East. Macmillan, 2001.

Goodhand. J. (2004). From war economy to peace economy? Reconstruction and state building in Afghanistan. Journal of International Affairs, 58.1, 155-174.

Goulden, R. (2011), Housing, inequality, and economic change in Syria. British Journal of Middle Eastern Studies 38.2, $187-202$.

Higgs, R. (2006), Depression, War, and Cold War: Studies in Political Economy. London: Oxford University Press.

Hinnebusch, R. (1997), Syria: The politics of economic liberalization. Third World Quarterly 18.2, 249-266.

Institute for Economics \& Peace .Economic Consequences of War on the U.S Economy. Sydney- New York- Washington D.C.(2011).

Johnson, C., Maley, W., Their, A., Wiirdak, A. (2003). Afghanistan's political and constitutional development. Humanitarian Policy Group. (K'erseas Development Institute Report).

Johnstone, S., Jeffrey M. (2011), Global warming and the Arab Spring. Survival 53.2, 11-17.

Kedourie, E. (2013), The Middle Eastern Economy: Studies in Economics and Economic History. Routledge.

Khater, A. F. (2005), "Becoming” Syrian" in America: A global geography of ethnicity and nation. Diaspora: A journal of transnational studies 14.2, 299-331.

Kedourie, E. (2013), Democracy and Arab Political Culture. Routledge.

Kelidar, A. R. (1974), Religion and state in Syria. Asian Affairs 5.1, 16-22.

Kelly, S. (2012), The claims of culture at empire's end. Syria and Lebanon under French Rule. Middle Eastern Studies 48.6, 1021-1022.

Lesch, D. (2011), The Arab spring-and winter-in Syria. Global Change, Peace \& Security 23.3, 421-426.

Malovany, P. (2014), Out of The North an Evil Shall Break Forth. International Publishing: Contento de Semrik Publishing. (Hebrew). 892-941.

Nasser, R. (2013), Socioeconomic Roots and Impact of the Syrian Crisis, The Syrian Center for Policy Research.

Nepstad, S. E. (2013), Mutiny and nonviolence in the Arab Spring exploring military defections and loyalty in Egypt, Bahrain, and Syria. Journal of Peace Research 50.3, 337-349.

Ohanian, L. E. (1997), The macroeconomic effects of war finance in the United States: World war II and the Korean war. The American Economic Review, 23-40.

Perthes, V. (1992), The Syrian economy in the 1980s. The Middle East Journal, 37-58.

Phillips, C. (2012) Syria's torment. Survival 54.4, 67-82. 
Sarıhan, A. (2012), Is the Arab Spring in the third wave of democratization? The case of Syria and Egypt. Turkish Journal of Politics 3.1, 67-85.

Seale, P. (2012), The destruction of Syria. The Washington Report on Middle East Affairs. 31,6, 11-74.

Simpson, C. (2011), Assessing the Arab spring in Libya and Syria: A compilation of varying statements from key actors. Connections: The Quarterly Journal 11.1, 55-67.

Stathis, G. M. (2015), ISIS, Syria, and Iraq: The beginning of a fourth gulf war? Critical Issues in Justice and Politics, 1.

Stiglitz, J. E., Linda J. B. (2012) estimating the costs of war: Methodological issues, with applications to Iraq and Afghanistan. The Oxford Handbook of the Economics of Peace and Conflict. New York: Oxford University Press. 275-315.

Stubbs, R. (1999), War and economic development: Export-oriented industrialization in East and Southeast Asia. Comparative Politics, 337-355.

UNRA, Syria-Alienation and Violence. Impact of Syria Crisis Report 2014. (2015):34.

Warren, R. (1940), War financing and its economic effects. Proceedings of the Academy of Political Science, 69-77.

Yang, B., Lester, D. (1994), The effect of war on the economy. Atlantic Economic Journal. Drexel University. 22. 3, 81-95.

Zisser. E. (2006), Who's afraid of Syrian nationalism? National and state identity in Syria. Middle Eastern Studies, 42.2, $179-198$.

Zisser , E. (2003), Face of Syria- Society, Regime and State. Israel: Hakibbutz Hameuchad Publishing. (Hebrew).

Zisser, E. (2014), .Syria-Protest, Revolution and Civil War. Israel, Tel Aviv: Dayan Center, Tel Aviv University. (Hebrew).

\section{INTERNET WEBSITES:}

kushnirs.org/macroeconomics/gdp/gdp_syria.html www.indexmundi.com/syria/gdp_real_growth_rate.htm http://databank.worldbank.org/data http://www.worldbank.org/en/country/syria/overview http://scpr-syria.org/en http://www.undp.org Syrian Centre for Policy Research for the United Nations Relief and Works Agency (UNRWA), Syria- The Syrian Catastrophe: socioeconomic monitoring report .first quarterly report (January - march 2013). http://trade.ec.europa.eu/doclib/docs/2006/september/tradoc_111615.pdf https://www.gfmag.com/global-data/country-data/libya-gdp-country-report https://www.cia.gov/library/publications/the-world-factbook/geos/ly.html 